\title{
A Socio-Religious Introduction to the Apostolic Churches in North America
}

Cory Anderson

Assistant Professor of Sociology and Geography

Department of Society and Environment

Truman State University

Research Associate

Department of Plant Pathology

The Ohio State University_Ohio Agricultural Research \& Development Center

\begin{abstract}
The Apostolic Christian Churches descend from the religious revivals instigated under the leadership of Samuel Fröhlich in 1830s Switzerland. Fusing Anabaptist thought into his revival through contact with Mennonites, Fröhlich’s movement constitutes a distinct religious tradition within the larger Anabaptist movement. Research about this Anabaptist tradition has remained sparse. This article helps introduce the Apostolics to a scholarly audience. It reviews the movement's recent history in North America, tracing the history of both the largest body - the Apostolic Christian Church of America-and several smaller, generally more conservative, factions. In addition to establishing links between the Apostolics and other Anabaptist branches, this article also outlines their distinctive properties, including not only their ritual forms but also four overarching, generalized socio-religious characteristics. These include: true repentance and death of the old man; gentle, reasoned pleading; affectionate fraternity of the repentant; and the personal leading of the Spirit through the Church.
\end{abstract}

\section{Keywords}

Samuel Fröhlich; Samuel Froelich; Apostolic Christian Church of America; Apostolic Christian Church Nazarean; Nazarene; Zion’s Harp; Repentance; Head covering; Religious ritual; Serbia; New Evangelism; German language; Religious division; Swiss Reformed Church

\section{Acknowledgements}

I am grateful to the many Apostolics who welcomed my wife and I into their midst.

Address correspondence to: Cory Anderson: Admin Building-Room 202, Ohio State OARDC, 1680 Madison Ave, Wooster, OH 44691; editor@amishstudies.org

Recommended citation: Anderson, Cory. 2018. “A Socio-Religious Introduction to the Apostolic Churches in North America.” Journal of Amish and Plain Anabaptist Studies 6(1):26-60. 


\section{Introduction}

The Froehlich tradition - today referred to as "Apostolic Christian" in America or "Nazarene" for the Eastern European counterpart-is in scholarship the most neglected of the seven plain Anabaptist religious traditions (Anderson 2013). The reasons are various. They are not as visually or institutionally conspicuous as other traditions. They have monikers often confused with other totally unrelated denominations, e.g. Church of the Nazarene, Apostolic Church, or Pentecostal Apostolic. They are concentrated far from centers of historic Anabaptist study, their concentrations being north-central Illinois, pockets across the eastern Great Plains, Eastern Europe, and Eastern European immigrant areas in urban North America. They have also historically secluded themselves from other plain Anabaptist groups. Some have not even considered themselves among Anabaptist movements but something totally unique.

In this article, I introduce the Froehlich tradition in North America. I open by situating the Apostolics within the wider plain Anabaptist religious tradition. I then point to developments in America since the early 1900s, especially the three main divisions, suggesting these divisions provide some clues as to what it means to be "Apostolic." I provide a population and geographic overview of the denominations, then follow with a short overview of Apostolic organizational structure. The next section walks the reader through the Sunday church ritual. Finally, I identify four overarching characteristics that define the Apostolics religiously and culturally.

The data presented here are based on exploratory mixed methods. Between 2010 and 2018, I casually visited in nine states the public services of 20 congregations - twelve Apostolic Christian Church of America (ACCA); three Apostolic Christian Faith (ACF); one Apostolic Christian Church Nazarean, East Conference (ACCN); one Nazarene Christian Congregation (NCC); and three Christian Apostolic Church (CAC); but no German Apostolic Christian Churches (GACC) due to visitor restrictions - making notes both during the services and afterwards. These, and other visits not including service attendance, included informative conversations with members; informative notes were taken after the visit, either that day or the next day. Information collecting focused on what Apostolics already understand to be general knowledge - facts of religious belief and practice — rather than interviewee opinions and attitudes. One intensive three-day visit in spring 2015 to the largest Apostolic settlement in North America — central Illinois, covering a range from Peoria to about 100 miles east—included ten informative interviews from a sample arranged by my hosts. Each interview involved from two to eight people and lasted from one to three hours. I transcribed interviews as they unfolded with a portable typing machine, focusing on recording key information and not every word spoken. I also collected and reviewed primary source documents, including information freely available at congregations, material posted on the web especially that focusing on the recent ACC-ACF division, hard copy documents not formally published but circulating among Apostolics, and books written by and about Apostolics. As this article concerns only a basic introduction to the 
Froehlich traditions and not a systematic analysis of specific social patterns, no coding of qualitative data was employed beyond simply organizing blocks of content thematically.

\section{Background}

The early origins and development of the Fröhlich churches need not be repeated here. Elsewhere in this issue and in other publications, Pfeiffer (2010; 2018) and Djurić-Milovanović (2010; 2018) detail their historic origins, pointing to the charismatic leader Samuel Fröhlich who left the Swiss Reformed church in the early 1830s to pursue a stricter, more devout faith. They also cover the migrations of Fröhlich's supporters to Eastern Europe and to the United States, places where many converted, including large pockets of late Amish-Mennonite migrants to North America, notably in central Illinois (Luthy 1986). These histories are in addition to two institutional, sympathetic chronicles Apostolic members have produced (Ehnle and Ehnle 2011; Klopfenstein 2008).

What are the Apostolics? Do they constitute an Anabaptist tradition, a completely independent tradition of their own, or a subcategory of Mennonite or Amish? The existing categorization schemes (Kraybill \& Hostetter 2001; Kraybill 2010) failed to either appropriately account for the Fröhlich traditions or to purposefully exclude them. Of the four traditions proposed-Mennonite, Amish, Brethren, and Hutterite-Apostolics were lumped into the Mennonite tradition, as if residual. Pfeiffer (2010:3-4) argues that Kraybill's protocol reflects not actual conditions but his "own genealogical lens [...] by which [he] understands normative Anabaptism,” and that evidently his "exposure to these groups was minimal.”

I concur with Pfeiffer, likewise arguing that the Fröhlich churches constitute one autonomous tradition within Anabaptism among seven (Anderson 2013). A distinctive Anabaptist tradition emerges from a new wave of converts' reinvention of core Anabaptist ideals, inspired by the fusion of a time-place context-specific expression of existing Anabaptism and additional ideals incompatible with established Anabaptist movements (e.g. plus Pietism to form Brethren, plus zealous adherence to the Dortrecht confession to form Amish, and plus the German Youth Movement to form the Bruderhof). Upon this new fusion, distinctive theologies and rituals emerge. These are recognizable by other Anabaptists yet reinvented so as to preclude an empathy that could lead to substantive collaborations or mergers.

The Fröhlich tradition fused a European-style evangelicalism characteristic of the time, including a strong emphasis on the abstracts of one's inner spiritual being, with a characteristically Anabaptist congregational regimentation emphasizing the inexcusability of absolute holiness for the repentant, plus the Anabaptist stance on nonresistance. The extent to which Apostolics made converts among other Anabaptist groups all the while maintaining ecclesiological separation reinforces the contention here that Apostolic / Nazarene churches constitute an autonomous Anabaptist tradition. 


\section{Managing the North American Context}

Compared to Amish and Mennonites, the frequency of Apostolic divisions is small. Yet, these divisions hold clues as to the Apostolic's definable characteristics. A certain practice or idea may lead to division for two reasons. First, it defines an essence of the group under the pressure of a replacement practice and adherence is an all-or-none. Those discarding the practice are moving toward assimilation because the essence is a core of identity. Second, an essence may be observed along a continuum, and hence, one side may de-emphasize it or hybridize it with other ideas without feeling they have betrayed who they are, while the other may stress the practice as evidence of continuity. In a division, the one side decries the essence's overemphasis; the other decries its deterioration. In these divisions, we can find clues as to a church's core-defining essences, a community habitus responding to new fields (Good Gingrich 2014, 2016; Reschly 2000, 2017).

North American Apostolics recognize three major divisions: 1905-07 (“first"), 1932 ("second"), and 2012 ("third"). For this introduction, I will chart recent history, picking up where Pfeiffer (2018) leaves off around the early 1900s. The history of divisions is charted in Figure 1.

\section{Figure 1: Timeline of Apostolic / Nazarene Divisions}

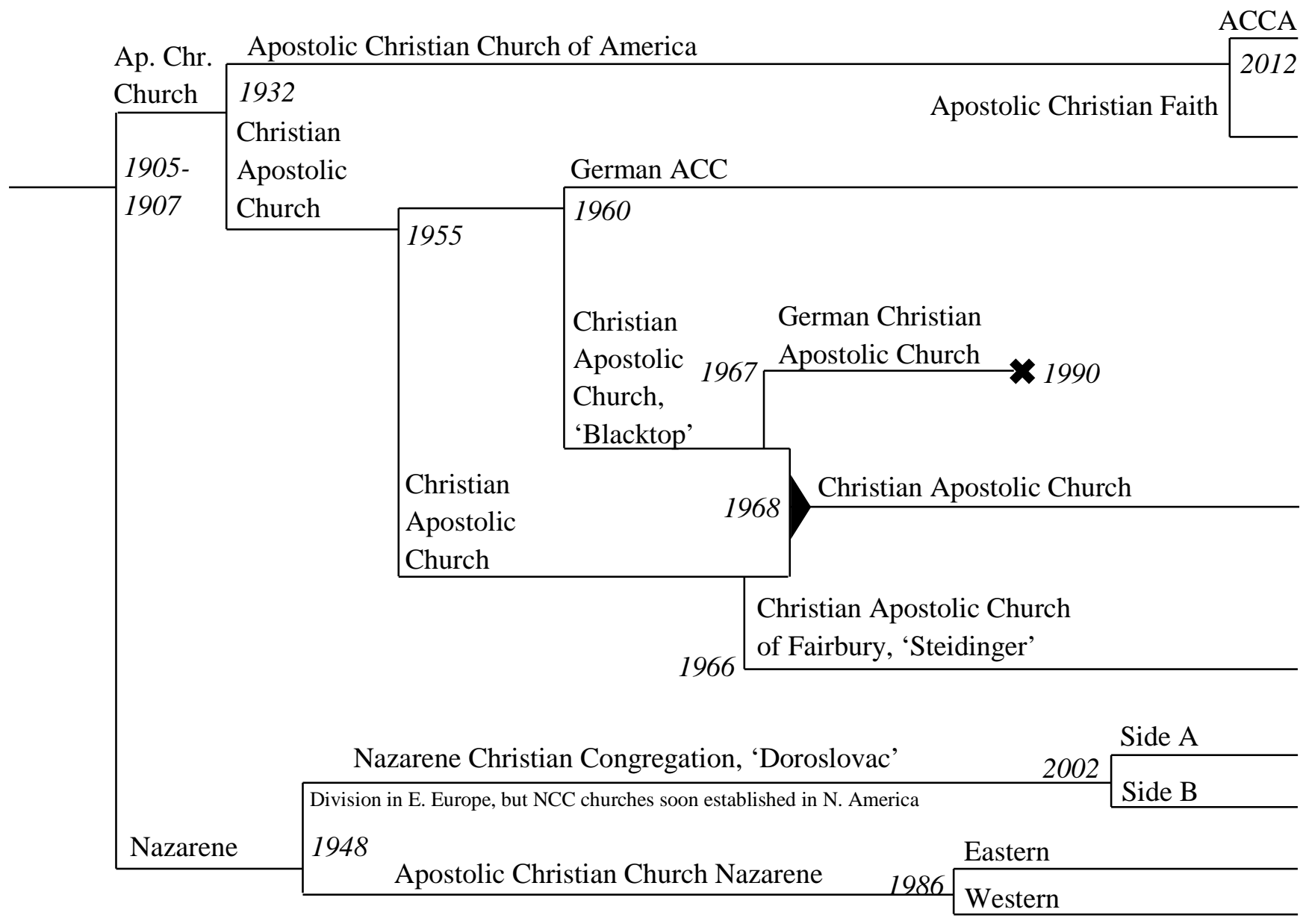




\section{The "First Split" and the Nazarene Branches in Europe and America}

The outcome of the first division was the Apostolic Christian Church of America and the Apostolic Christian Church Nazarean, ${ }^{1}$ although these names were not formal at the time. Klopfenstein's (2008) account is the most well-known, albeit not quite as thorough and impartial as would be desired. He characterizes the Apostolic churches as widely scattered and without much central direction, including, for many congregations, the lack of a local elder. Into these conditions walked a mass of diversities. Unity was difficult to achieve due to the variety of religious backgrounds_-Amish-Mennonite, Lutheran, Catholic, various Protestants_-and ethnic backgrounds - Swiss, German, Austrian, Hungarian, and French. Klopfenstein also suggests that the Amish-Mennonite coverts, the majority, brought traditionalism and a non-evangelical spirit with them, contrasting with fresh European converts from non-Anabaptist backgrounds who were more educated, urban, and outspoken. Klopfenstein further suggests that slow communication among elders-especially the Trans-Atlantic communication since the denomination was intercontinental-hampered efforts at resolution. A strongly symbolic token of differences was the objection of many with Amish-Mennonite background to the mustaches of migrants from the Balkans, as the former wore beards without mustaches at the time. After the division, the Nazarenes retained a stronger sense of European ethnicity, due to the fact that European elders supported the Nazarenes while American elders stood with the ACCA element.

The ACCN side had assimilationist tendencies in America. In 1986, the ACCN instigated a districting, the East and West Conference, which was actually an internal division. Congregations did not follow this geographical dissection of North America perfectly but rather followed ideological lines. The West is basically religiously assimilated today. The East contains a mixture, with some congregations basically assimilated and others still holding modest and gender-distinctive dress, the woman's head covering, and some stigma on entertainment technologies. Within the past couple of years, the East Conference has distanced itself even further from the West by no longer listing congregations together in the same directory.

The Nazarenes in Eastern Europe are more distinctive than their North American counterpart, to the point where the main body of Nazarenes primarily associates with the ACCA in America, not the ACCN. The European Nazarene strictness may be owed in part to the difficulties of the communist era versus the sudden material ease of Nazarene migrants to America. The communist era brought hardships to the church, in both persecution and in church unrest over their response to government demands (Djurić-Milovanović 2010). Nazarenes remained united in their refusal to carry weapons, and, in prisons, were often beaten. They did not, however, remain united in their decision to join agricultural collectivities or participate in political life. In 1946, elders met in Vrbas, Serbia, in response to the post-war communist changes and agreed: no voting, no political parties, no agricultural collectivities, no unions, and no carrying weapons (Bojan 1999). Over the next two years, the Nazarenes suffered immense abuse for these positions (Nenadov 2006). In 1948, 42 members reconvened in Stara Pazova and formally rejected the 1946 stance. Those committed to the 1946 stance tried, unsuccessfully, to 
prevent this meeting. They scheduled another meeting to affirm their stance but the organizers were arrested. Elder Milorad Doroslovac was the figurehead of those resisting compromise. With the support of the Western European Apostolics, Serbian elders forced his resignation, against his will, and effectively divided the church. Attempts at reconciliation in the following years failed. The Doroslovac side — or the Nazarene Christian Congregation — suffered immensely during the late 1940s through the 1950s, especially with many imprisoned husbands / fathers (Bojan 1999).

Beginning in the 1960s, both sides had migrants to the United States, the accommodating side largely joining the ACCN, the Doroslovac side establishing their own congregations. In 2002, a difficulty among the NCC in Serbia divided the NCC on both continents. On a single occasion, a young woman and her non-Nazarene boss became physically involved (without fornication). The young woman soon confessed. The NCC was divided on whether she should be immediately restored or disciplined. Side A favored restoration, Side B discipline. Another version relates the division to elder-based decision-making versus congregation-based decisionmaking, perhaps over this particular matter.

\section{The "Second Split" and the German / Christian Apostolic Branches}

Among the ACCA, the second split occurred February 7, 1932. Elder Martin Steidinger of the South Side church near Fairbury, IL, withdrew from the ACCA, with members following from Illinois (Cissna Park, Elgin, Fairbury/Forrest, and Tremont), Oregon (Silverton), and Kansas (Sabetha), to become the Christian Apostolic Church. Within the South Side church, the agitations contained two familiar ingredients in divisions - conflicts in practices and power dynamics (Klopfenstein 2008:418-20, Nussbaum and Babbs 2003[1973]:60-63)—ones nearimpossible to sort out almost a century later. This was arguably an Old Order-conservative division, the last of a series across plain Anabaptist traditions:

- the Old Order Amish, coming from the Amish-Mennonites in the 1860s

- the Old German Baptist Brethren, coming from the Church of the Brethren in the 1880s

- the Indiana, Pennsylvania, Ontario, and Virginia Old Order Mennonites, coming from their regional conference in the 1880s-1900s

The later timing is probably due to the Apostolics being the last to migrate to the United States and the time required for second and third generations to accept simulation pressures. Similar to the other Old Order movements, the Steidinger segment was alarmed at assimilation pressures, specifically, members attending the funeral services of other denominations, shifts away from simple and modest dress, the loss of the German language, and the casualness in which some other elders viewed these issues. For the new group, compromising in worldliness is to compromise the faith. Indeed, today, all branches descending from the Steidinger side of the division maintain the conviction of simpler, distinctive dress and lifestyle practices more strongly than the ACCA, though none have limits on convenience technologies. Only the German Apostolic Christian Church retains, to some extent, the German language. 
After two decades, circumstances allowed Elder Emil Hari of Oregon to exercise unusual influence in the church, with the backing of European leaders in their denomination. He stressed practices of dress, German language adherence, and non-fraternization, to the extent of alienating two groups that divided off in 1955 and 1960. These both took the CAC name with them. Institutional continuity remained in Hari's group, which assumed the name German Apostolic Christian Church. The first group included congregations in Silverton, OR, and Forrest, IL, and possibly another one or two. The second division, in 1960, took churches in Sabetha, KS; Peoria, IL; and Fairbury, IL, where the group was called the "Blacktop Church.”

After about a decade, and given the relatively small size of the two CAC groups, some cooperation was desired. This was facilitated by each somewhat relaxing their practices in 1968, but not before factions on both sides withdrew. From the 1955 CAC side, the Christian Apostolic Church of Fairbury (aka "Steidinger church") emerged, feeling that the CAC was compromising by overlooking some new clothing fashions, softening on attendance at other denominations' funerals, and nudging out the German language. The CAC of Fairbury continues to today, although the church has no children or friends attending. The youngest members are in their upper 30s. English was accepted after a generation passed. The faction off the Blacktop Church—officially the "German Christian Apostolic Church" but colloquially referred to as the "house church" — continued for two decades. While it began with 40-50 people, it dwindled, so that by 1990 it closed due to defection to ACCA. The church retained German in services during those years, with some English.

The merged Christian Apostolic Church remains to today, though they experienced a sizeable defection in their churches to ACCA during the early 1990s. In addition to any restlessness from within CAC, ACCA members were successful propagating the idea that the 1932 division "should never have happened.” Many of this period's CAC defectors eventually moved beyond ACCA churches. The largest CAC congregation is in Forrest, IL. A merger with the Faith church has been off and on the table since the Faith church's emergence. The GACCA has remained quite private. Members refuse to discuss religion with non-members and nonmembers may not visit services. The successor of Emil Hari was his son, Robert, who is currently in a nursing home. The GACCA is heavily stigmatized by other Apostolic groups as reclusive, dictatorial, and rules-based; the GACC's refusal to talk religion means that the sympathetic view from within must remain unaddressed, at least here.

\section{The “Third Split”: Apostolic Christian Faith}

The reverberations of the 2012 division are still being felt, its final consequences yet unclear. (The division was, in my opinion, one of the messiest and most complex I have seen in Anabaptist churches.) The timeline points to no early days or clear origin. The catalysts leading to the division were multiple, as were the layers at which personalities clashed, from the elders to ministers down to the laity and single's groups, and then even clashes across these levels. This may well be the swollen consequence of 80 years without institutional division. The ACCAs 
have not yet had a mainstream-conservative division as had happened in the early to mid-century Swiss Mennonites, Amish-Mennonites, and Brethren experienced. It's possible this may be the delayed mainstream-conservative division, or it may be something different.

Where the story begins is impossible to pinpoint, for it seems bottomless, perhaps back to 1932. If we can put our finger on one external cause of the 2012 division, it would be the extent to which mainstream Western thought and practice can be comfortably hybridized into the Apostolic religious cosmos while remaining true to the faith delivered. If an internal cause can be pinpointed, it would be the sweeping centralization and institutionalization of the denomination after the 1932 division. This had the effect of administratively pushing the lid on the boiling pot down so hard in the name of unity that when it finally blew, it blew.

Changes occurred in at least three directions that would have consequences for a division. First, Apostolics accepted urban living much more than other plain Anabaptists. The first church to drop roots in an already urban area was Chicago, established in 1926, with additional churches following - Los Angeles, Wichita, Detroit, Sarasota, Fort Lauderdale, Phoenix, Minneapolis, and Indianapolis - through the 1960s. The trend has continued since. In general, urban churches more readily accept mainstream American cultural innovations and are less ready to defend particularly Apostolic thought and practices. The outcome is hardly unexpected, though explaining why is another matter for another time.

Second, Apostolics became quite wealthy. Rural Apostolics settled many areas of prime agricultural land, namely north-central Illinois, which is one of the most highly mechanized crop farming regions in the country. With no qualms about accepting technological innovations, the Apostolics could expand operations. Others moved into the professional careers, both the trades and, unlike many other plain Anabaptists, white collar professions-accounting, management, finances, psychology and counseling, retail and sales, social work and human services, health, public school teaching, and such. Many of these careers required a university degree, so by the 1990s, Apostolic young adults_-both friends and converts_-were regularly enrolling in postsecondary education programs, from community colleges to large state universities such as the University of Illinois, Purdue, and Iowa State.

During this era, Apostolics invested heavily in their denominational infrastructure. Many of the current brick-style, single-floor meetinghouses were constructed, which are generally among the largest and most solid of plain Anabaptist church structures, even as they retain their simplicity (see Figure 2). Denominational programs and institutions were established, and intercongregational travel became quite common. With increased income, their standard of living also went up, which placed pressure on the common outlets for excess wealth that plain Anabaptists traditionally proscribe, namely dress patterns, residences, recreation and leisure, educational attainment, and consumer goods. Certainly standing beside other plain Anabaptists today, the Apostolics are not alone in dealing with changes in wealth, though their acceptance of higher education is one distinctive. 


\section{Figure 2: A Conventional Apostolic Meetinghouse, Jeffersonian Style}

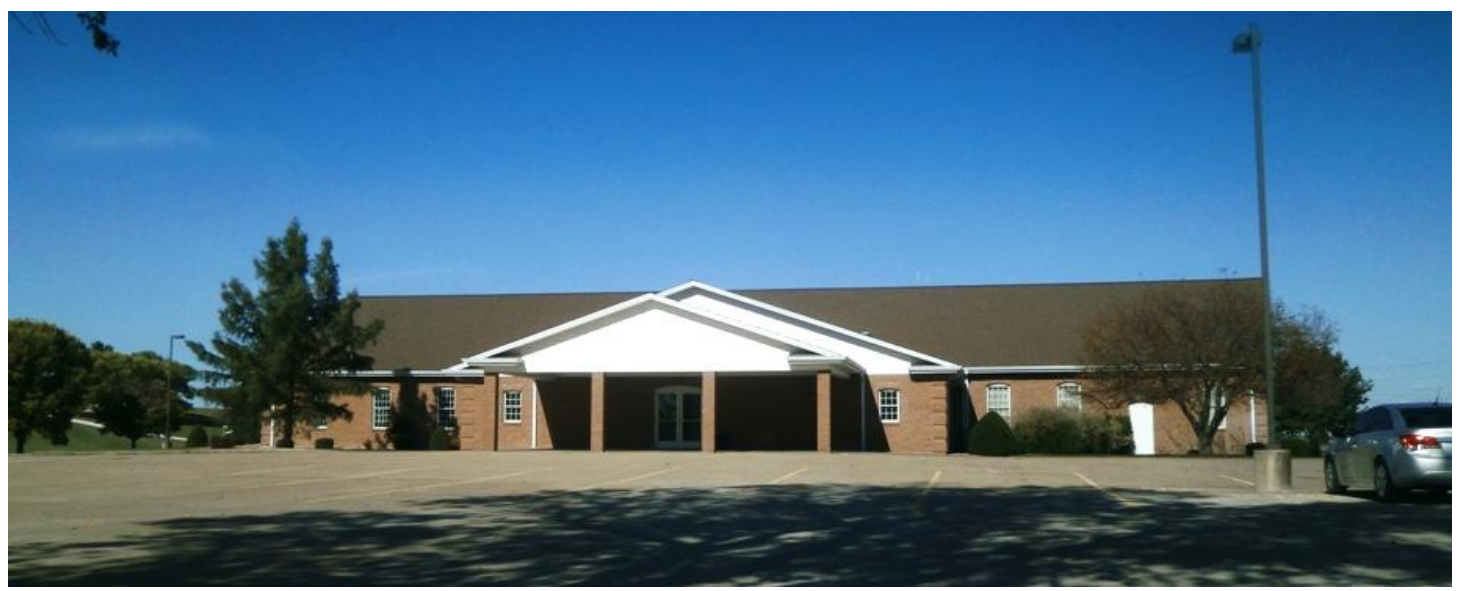

Third, Apostolics, despite their prohibition against attending outside denominations' church services, have nonetheless absorbed influence of what critics call "New Evangelism.” If the phrase was not already popularized by the 1986, it was when in that year the elder body released the booklet Winds of Doctrine. The aim of this well-footnoted booklet was to distinguish between Apostolic doctrinal emphases and those of popular evangelism, whose protégé may best be captured in contemporary, motivational-style Christianity. This book was championed by some, touched a nerve in others. Today, it better represents the concerns of the ACF elder body than the ACCA elder body, even as it remains the official publication of ACCA and is neglected by ACF due to the primary author abandoning its arguments in favor of the change-minded position. In ACCA, popular Christian thought may show up as:

o a moderate stigma against Apostolic denominationalism, traditional worship structures, Apostolic-specific religious practices (the so-called “works” religion), and emphasis on founding religious leaders

o an emphasis on inspirational religious content, hybridizing the content of sermons, prayers, and religious conversations

o acceptance of the casual contemporary image, from dress styles to suburban-style homes and décor

o music preferences, more in listening tastes than congregational singing.

As for the actual events leading up to the division, for many years, the Apostolics had a progressive-leaning and a conservative-leaning wing. They functioned as one denomination, even as visiting and relationship patterns tended to be within the given camps. The elder body tilted in the conservative direction, and a smaller Elder Committee was similarly composed of conservatives. Between the time of the Winds of Doctrine booklet and the mid-2000s, the body and the Elder Committee moved in a moderate direction. Moderates are generally underconceptualized but are important forces during divisions. Broadly speaking, moderates 
emphasize institutional expansion, organizational unification, and mediation; they stigmatize zeal, firm convictions, social action outside conventional means / institutions, and, above all, institutional division. Moderates are likely to derive their influence during eras of polarization. They may be claimed by both progressives and conservatives simultaneously; moderates may be aware of this but throw their lot to neither.

When moderates came to power, they prioritized a greater unity and centralization within the denomination. If such centralization brought dissatisfaction to members, liberals could (and did) defect to non-denominational and Baptist churches. The conservatives, on the other hand, had no alternative, or at least they did not consider the CAC and German branches alternatives. They had to either assimilate or resist any pressure to yield their positions. Some conservative elders or other ministers were silenced through conflicts arising from their resistance, while others chose to remain silent in the face of conflict. The Elder Committee's involvement in the Rittman, OH, church, one of the largest, in the mid-2000s resulted in the Committee's silencing of the conservative elder, interpreted by conservatives as an ominous act.

During these tense years in the 2000s, many informal debates occurred at the lay level. For example, conservatives monitored sermon content and pinpointed phrases or ideas sourced from new evangelism or new age-inspired business management philosophies (e.g. the diaprax of mega-church pastor Rick Warren). Progressives, and eventually some moderates, framed conservative defenses as traditionalism and legalism rather than Biblicism. Some progressives used the web to disseminate their positions. One ex-Apostolic on the progressive end, for example, wrote against the "Preservation Movement" positions, arguing that their doctrines are heretical. ${ }^{2}$ In addition to web content, many written materials were copied and passed around among members, especially the conservatives, trying to convince family members and religious brothers and sisters to hold their position. These materials were not just one-page pleas; extended essays and even books emerged. ${ }^{3}$ The literature leading to the division was proliferous.

The impetus for the division was when some Morris, MN, members—dissatisfied with their elder's stricter position on true repentance and conversion—contacted the Elder Committee to investigate, who silenced this elder and restored a retired elder, Roy Koehl, to leadership. The elder body also established a neighboring congregation for dissatisfied members, North Morris. However, unrest remained at Morris, as Elder Koehl also held to stricter positions. The Elder Committee returned, requesting that Koehl either retire or allow the Elder Committee to make changes, especially concerning how new converts are accepted. The difference was over these positions: (1) past sin is forgiven with Jesus's blood at conversion and sin then becomes a rare occurrence for the believer, whereupon the advocacy of Jesus before God is sought; (2) if sin, though not desired, continues to be with the believer, it is justified through Jesus's blood. Certainly, the historic Anabaptist emphasis on the total holiness of the believer in the brotherhood is characteristic of the first position while the latter is characteristic of the Protestant-Calvinist tradition. So the difference on this one point really captures an overall 
orientation toward Anabaptism versus Protestantism, of strict past precedent in the religious tradition or a willingness to hybridize.

Koehl met with church members, who by-and-large supported him. The Elder Committee returned and held another meeting; those supporting the Committee were present and agreed to the dismissal of Koehl. The other members met again, reinstated Koehl, and voted to leave the ACCA. Several months later, the ACCA, which holds all meetinghouse property titles, requested the group discontinue meetings there, which was honored. This event was the precipitating factor necessary for dissatisfied groups across the country to withdraw. That year, groups withdrew from Lester, IA; Lamar, MO, which had also been under investigation by the Elder Committee; Eureka, IL; and Rittman/Smithville, OH, the retired elder eventually joining them. After a little over a year of news of one division after another, the withdrawal was largely complete. Key leaders adopted a revised statement drafted and signed two years prior by Preservation Movement advocates, entitled “This We Continue to Believe.”4

The Apostolic's strong sense of loyalty and affection for their people made this particular division very difficult. What is more, it failed to distribute people to the correct side of the fence. Conservatives not yet willing to leave the ACCA body felt the division split the conservatives between two denominations. Some low-key efforts remained within ACCA in hopes of a more amicable division, but at this point, no evidence has come to my attention that the elder body will concede a proactively coordinated additional division. After institutionally mobilizing against conservative activism, the moderate leadership appears intent to hold control, consistent with past institutional strategies in Amish (e.g. Gingerich 1986) and Mennonite (e.g. Kniss 1996) divisions. Conservative leaders in ACCA appear reticent to speak forthrightly about concerns, perhaps given the precedent of elder body intervention when alienated local members appeal for investigation. Many of the conservatives remaining are in generally conservative churches that experienced either sizeable divisions (e.g. Mansfield, OH; Bloomfield, IA; or Eureka, IL) or no local division because tensions were not felt locally (e.g. Akron, OH). Fear of retribution-such as losing the meetinghouse or receiving a stigma - and loyalty to God's placement in the denomination may also factor into some laity and leader decisions not to leave. Some fraternization continues between ACF and ACCA conservatives, who, if the latter are sympathetic to ACF, are quietly so.

On the ACF side, rest and unity is hardly the result, though the issues now are new. For one, will they discontinue their acceptance of divorced-and-remarried couples repenting and becoming members? Doing so would require releasing some among their number but would also open possible relations with the Christian Apostolic Church. ${ }^{5}$ For another, is ACF just trying to continue ACCA practices prior to the most recent changes or are they going to re-evaluate and strengthen their practices, e.g. more distinct clothing and larger coverings for women. The latter, advanced by a group of young to middle-aged intellectuals, is certainly the minority position, since it may lead ACF into new unknown areas. This second ACF leaning finds some inspiration from the Remnant (“Charity”) and "Kingdom Fellowship” (David Bercot-type or "Berne, IN 
meetings”) movements. Positioning themselves in contrast to conservative and Old Order Amish and Mennonites, the Remnant and Kingdom movements stress an Anabaptist ecumenicalism of the true believers, charismatic leadership, homeschool-style family-strong strictness, and deference to authentic-early-church-ism (e.g. the church fathers and 1500s Anabaptism). To some in ACF, such a bridge is no better than the bridges to other denominations that compromised the ACCA; to advocates, these bridges provide the theological currency needed to justify a strengthening of practices. To date, a handful of ACF members have defected to these charismatic movements.

At present, ACF views itself as continuing the tenants of the true faith against an apostatizing mother body. The ACCA views the ACF as dogmatically stressing doctrines of men that caused faction. Certainly such simple explanations conceal deeper complexities. But for now, further musing to discover more nuanced conclusions in such limited space is unfitting.

\section{Population and Geographic Distribution}

The Apostolic Christian Church of America is by far the largest body, with the Apostolic Christian Faith and the Apostolic Christian Church Nazarean as moderately sized. Five small factions number under 200 members each (see Table 1).

Figure 3 shows the distribution of congregations across North America. The congregations of the Apostolic Christian Church of America have their core in central Illinois, in a range stretching largely east to west. The 30 miles between Peoria and Bloomington is the densest region. US-24 between Peoria on the west end and Forrest on the east is the Apostolic's equivalent of 340 in Lancaster County, PA; 39 in Holmes County, OH; and 20 in ElkhartLaGrange Counties, IN-a great place to go Apostolic spotting. Beyond this region of Illinois, Apostolic congregations spread farther east and west, east into the northern half of Indiana, the Indiana-Ohio border, and northeastern Ohio. To the west, congregations are spread throughout Iowa, with a few in Minnesota and Kansas. Nearly all other Apostolic congregations outside this Midwestern Apostolic region are in urban areas. By and large, these small congregations are the result of Apostolics taking professional occupations.

The congregations of affiliations stemming back to the 1932 (CAC / German) and 2012 (ACF) divisions are in places no different than ACCA churches. Of the small groups, ACF churches are the most diffuse. Of all ACCA locations, ACF churches were more likely to start in central Illinois, Iowa, Ohio, and in rural areas. Hardly any urban congregation had a Faith-church division. Eight Apostolic communities today have small buffets of affiliations (Table 2).

The Nazarene branches of the so-called "East Conference"-distinguished from the now mainstream "West Conference"-are located exclusively in urban and suburban areas, due to the vast majority consisting of relatively recent migrants from Eastern Europe. They are located in the metro areas of Los Angeles-San Diego, Detroit, Cleveland-Akron, New York City, and Tampa. 


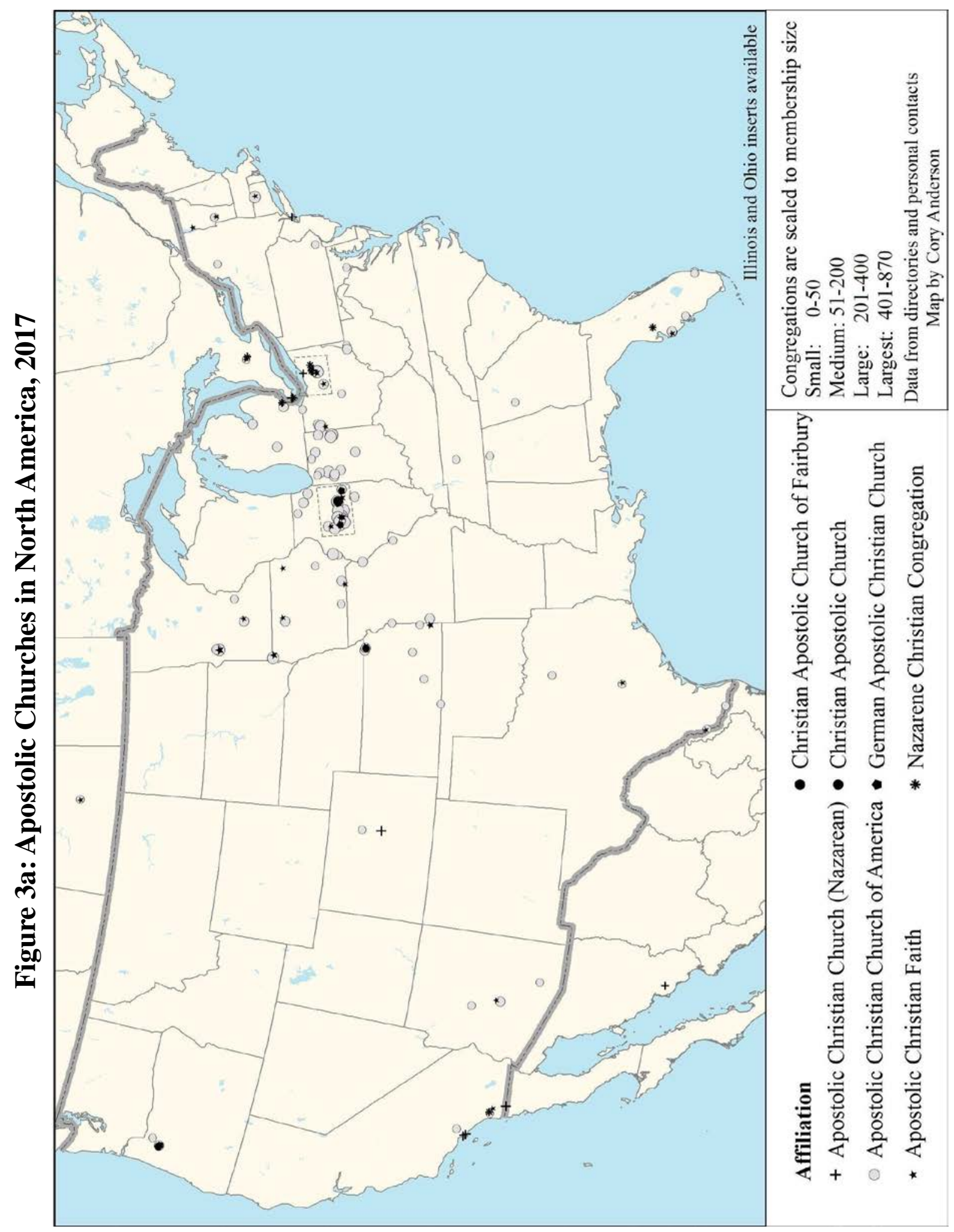




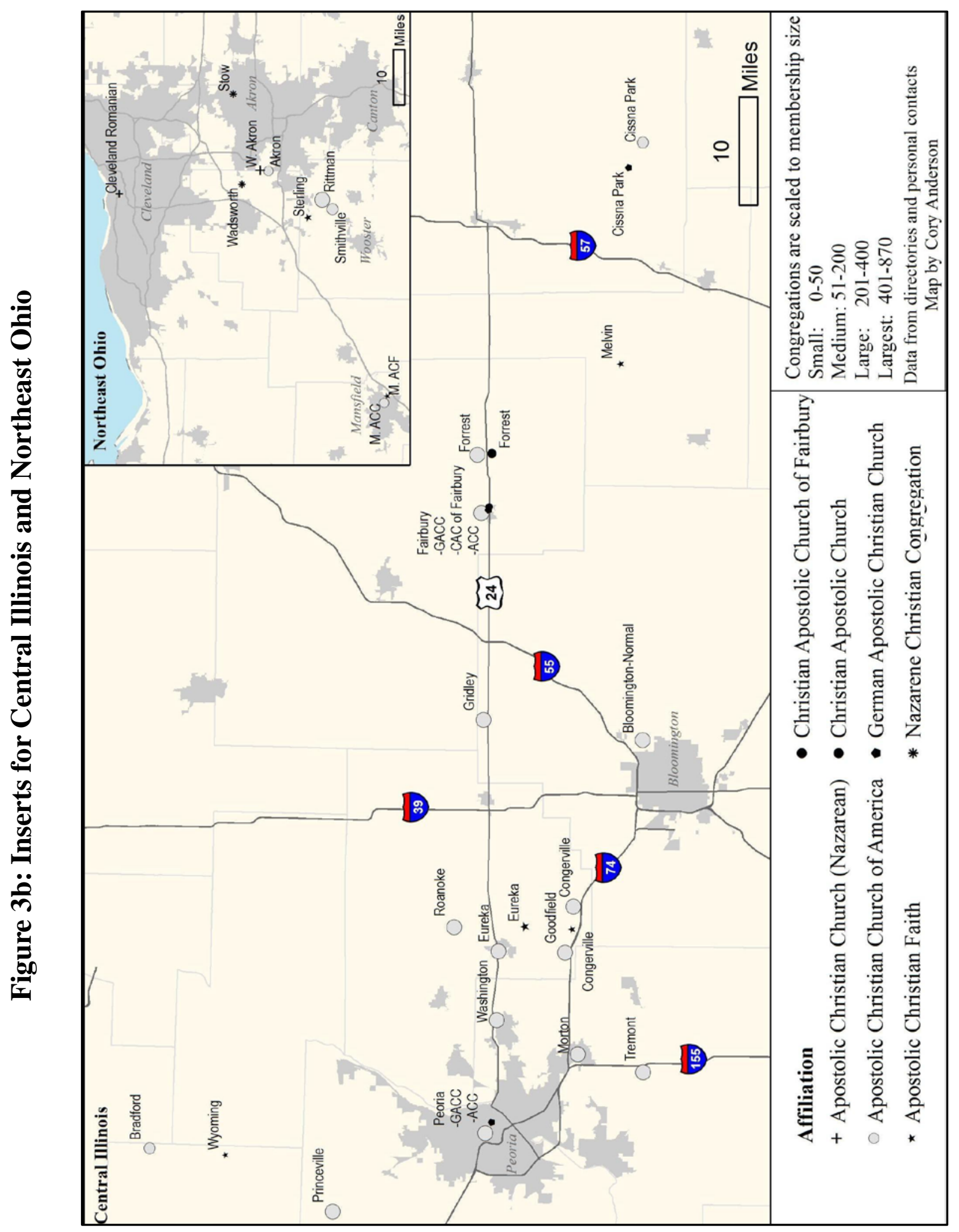




\section{Table 1: Population for the North American-Based Apostolic Denominations}

\begin{tabular}{|l|c|c|}
\hline & Members & Congregations \\
\hline Apostolic Christian Church Nazarean (East Conference) $^{\mathrm{a}}$ & 2,212 & 35 \\
\hline Nazarene Christian Congregation, Side A $^{\mathrm{b}}$ & $\sim 100$ & 6 \\
\hline Nazarene Christian Congregation, Side B $^{\mathrm{b}}$ & $<100$ & 5 \\
\hline Apostolic Christian Church of America $^{\mathrm{c}}$ & 11,365 & 96 \\
\hline Apostolic Christian Faith $^{\mathrm{d}}$ & 978 & 26 \\
\hline German Apostolic Christian Church $^{\mathrm{f}}$ & 150 & 4 \\
\hline Christian Apostolic Church $^{\mathrm{e}}$ & 130 & 3 \\
\hline Christian Apostolic Church of Fairbury "Steindinger"f $^{\text {"f }}$ & 28 & 1 \\
\hline TOTAL & 15,063 & 176 \\
\hline
\end{tabular}

${ }^{a}$ Based on the 2017 ACCN North America Directory; West Conference omitted as no longer plain

${ }^{\mathrm{b}}$ Membership based on rough estimate, congregations based on personal contact in 2016

${ }^{\mathrm{c}}$ Based on the 2016 ACCA Directory

${ }^{\mathrm{d}}$ Membership (estimate) and congregations based on personal contact in 2015

${ }^{\mathrm{e}}$ Based on 2016 directory, membership estimated from households listed

${ }^{\mathrm{f}}$ Based on personal contact in 2015

\section{Table 2: Apostolic Communities with Three or More Affiliations}

\begin{tabular}{|c|c|c|c|c|c|c|c|}
\hline & $\begin{array}{l}u \\
Z\end{array}$ & $\begin{array}{l}{ }_{Z}^{*} \\
\underset{Z}{U}\end{array}$ & 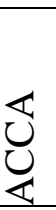 & $\underset{\ll}{U}$ & $\underset{U}{U}$ & $\stackrel{U}{\circlearrowright}$ & 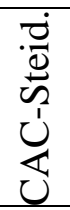 \\
\hline Sabetha, KS & & & $\bullet$ & $\bullet$ & & $\bullet$ & \\
\hline Salem, OR & & & $\bullet$ & $\bullet$ & $\bullet$ & $\bullet$ & \\
\hline Fairbury / Forrest, IL & & & $\bullet$ & $\bullet$ & $\bullet$ & $\bullet$ & $\bullet$ \\
\hline Cissna Park / Melvin, IL & & & $\bullet$ & $\bullet$ & $\bullet$ & & \\
\hline Rittman / Akron, OH & $\bullet$ & $\bullet$ & $\bullet$ & $\bullet$ & & & \\
\hline Kitchener, ON & $\bullet$ & $\bullet$ & $\bullet$ & $\bullet$ & & & \\
\hline Detroit, MI & $\bullet$ & $\bullet$ & $\bullet$ & & & & \\
\hline Escondido, CA & $\bullet$ & & $\bullet$ & $\bullet$ & & & \\
\hline
\end{tabular}

*Only includes congregations within the East Conference that are still conservative in practice

Outside of North America, the ACCA has two congregations in Japan and five in Mexico; the ACCN has two in Mexico. The Nazarenes have sister congregations in Eastern Europe across several affiliations, with particular concentrations in Hungary, Serbia, Ukraine, and Romania, although the ACCN is not in full fellowship with these. The ACCA parallel in Switzerland and Germany is basically assimilated, a process occurring from 20 to 10 years ago.

The German Apostolic Christian Church has long maintained associations with a European body, Taufgesinnte Gemeinde, but these relations have been recently severed. 
Germany and Switzerland have 10 congregations and an estimated 350-380 members with up to 1,900 in attendance-members, children, and friends - and unlike the U.S. GACCA church, appears to be on a membership rebound after a low two decades ago. ${ }^{6}$

In Serbia, the NCC has around 12 churches and 200-300 members inclusive of both sides, while the ACCN is much larger, around 50 congregations in Serbia, ${ }^{7}$ plus congregations in Hungary and several other countries. These numbers are actually very low, in historical perspective. Around 1900, they numbered 15,000 baptized members in Serbia alone, whereas by 2010, the country had just under 1,000 ACCN members (Djurić-Milovanović 2010).

\section{Organizational Structure}

For Apostolics, leadership at the congregational level consists of deacons and one elder, collectively called "the ministers." The size of the ordained brethren generally correlates with the congregation's size. Ordained deacons are elected by popular vote from within the congregation, though usually a small handful or even one man is the obvious choice, and the affair is without politicking. Elders are elected from among the deacons, and the Elder Body must approve the decision. The Elder Body consists of all elders.

Most congregations have their own elder, although very small (usually urban) and new congregations may use another church's elder. Deacons preach while elders, who also preach, administer the sacraments, baptize, and discipline members. Non-ordained deacons may also be appointed when an elder cannot be elected for some reason. The non-ordained deacon takes care of local matters the elder would otherwise handle.

The Elder Body confers regularly and makes decisions about practices and discusses concerns, recording decisions in minutes. In the mid-1900s, a committee within the ACCA Elder Body was formed to develop agendas for meetings, a shift that proponents felt was necessary given the growing Elder Body size. The ACF eventually came to see the Elder Committee as a site of inequality that privileged the moderate element's emphasis on tolerance. They did not reestablish this committee when reorganizing as a separate affiliation. In ACCA, elders gather six times a year, most often in regionally-based small group meetings, then twice a year as a full body. One of these is during an annual convention. Elders meet for a day, then all ministers. The final day is an open, denomination-wide inspirational meeting.

In addition to the denominational structure, the Apostolics manage several service programs, including nursing homes, foreign material aid, counseling and other social work services, publications (e.g. “The Silver Lining” periodical), several patron-owned private schools (Apostolics mostly use public schools), and an historical center. Some organizations have appointed church representatives. Representatives assemble periodically for meetings. The representative structure is a way for institutions to extend influence into all churches, including those ambivalent about a given program. Annual benefit auctions are common and are usually held on-site. Bidding typically approaches or exceeds the actual value of items on the block. 


\section{Ritual Order: The Apostolic Christian Church Service}

The Apostolic Christian Church, Apostolic Christian Faith, and Christian Apostolic Church (and presumably the German ACC) have very similar ritualistic order for a church service, going something like this. Many attendees arrive 20 minutes or more prior to the formal time of opening. Immediately prior to or upon entry, women, most having long hair in a bun, will don a special covering for the service, a long black lace piece that lays atop the head and hangs down the sides and below the shoulders (Figure 4). As people arrive, they mill about in a foyer area. For many older meetinghouses, the foyer is between the main entrance and the upstairs sanctuary. For many newer meetinghouses (e.g. Figure 2), attendees enter the long foyer from the short ends, with the sanctuary running along one long end and the dining hall the other. Men and women intermingle, shaking hands; for more conservative and smaller settings, the hand shake is accompanied with the phrase, “Greetings, brother / sister” and a cheek-to-cheek kiss within each gender.

\section{Figure 4: Two Conservative Examples of the Long Lace Veil for Church}

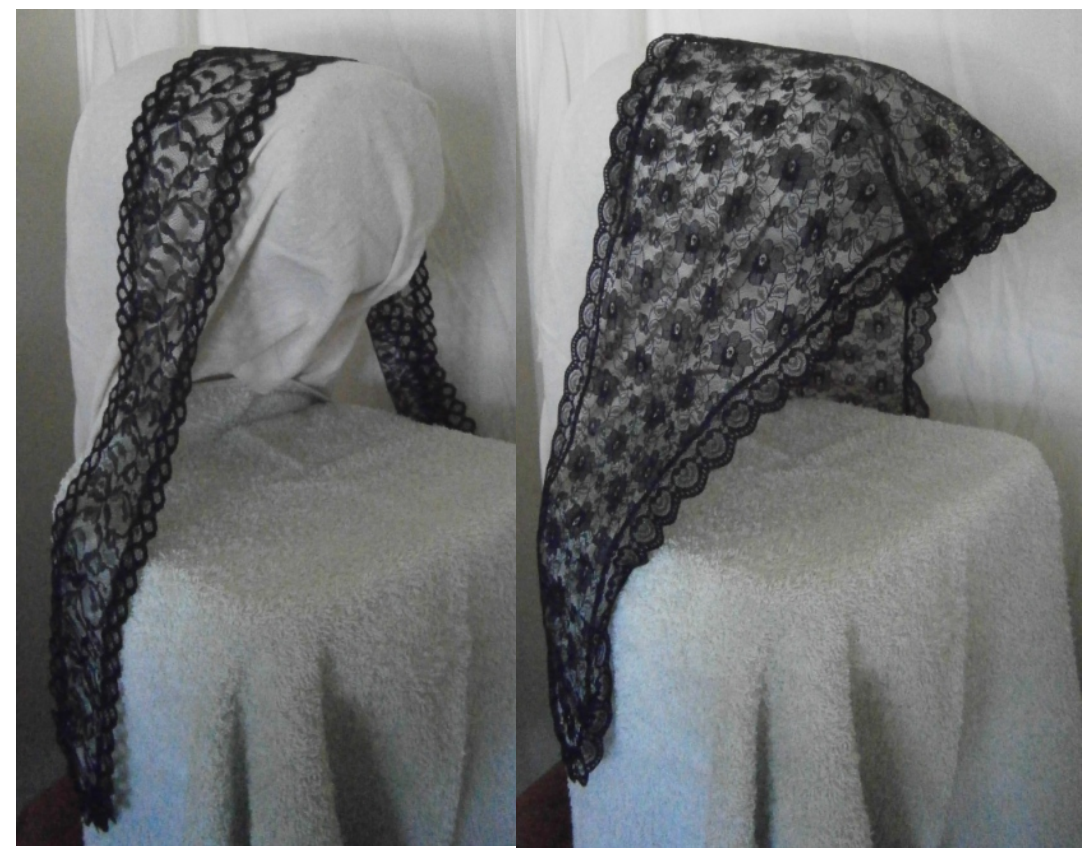

Photos by Cory Anderson

About 10 to 20 minutes prior to a service's opening, men and women, seated on separate sides of the congregation, will start four-part, a cappella singing from Zion's Harp. The Zion's Harp is a European-era hymnal of 253 selections, translated not only into English from German but also Serbian, Romanian, Hungarian, Slovakian, Spanish, Portuguese, and Ukrainian. The service formally opens when singing ceases and the ministers walk from a front pew to the seating behind at the rear of an elevated pulpit area. They bow their heads in silent prayer for around a minute, as does the assembly. After the prayer-which has no formal, synchronized 
conclusion-ministers lean in to one another, whispering quietly and succinctly, nodding, with the one to speak becoming unexpressive and glancing downward; they are encouraging the one who is to speak.

A minister then rises, often a visitor if one is available, and offers a short opening (optional). He then, under the guidance of the Spirit, opens the King James Bible to a random Old Testament page and selects a passage_-often a single chapter-to read, usually based on where his eyes land. The assembly has Bibles in the pews, and most follow along. Comments may precede and/or follow the passage reading, although commonly no additional thoughts are provided. Ministers are impressively eloquent in reciting obscure places and names, owing perhaps to being trained to use in-text pronunciation markings.

The minister then opens to a random Zion's Harp hymn, announces a number, and takes a seat. A layman starts the hymn, with barely a beat's lag until the congregation joins him at full force. The same minister then calls everyone to prayer. Most kneel forward on both knees, propping their arms atop the bench back to their front. Leaders kneel forward on a short partition extending out sideways from the pulpit and separating the raised area from the front row of congregational seating. A few among the assembly may kneel backwards, resting themselves on their pew's seat; this is more common among the elderly, young mothers, children, and those approaching the service with informality. The minister offers an oral prayer of around four to seven minutes. Nearly all children and many adolescents do not participate in the prayer, instead conversing or playing with toys in the pew or on the floor. Young parents may join their children in these activities.

Following prayer, the same minister rises to the pulpit and, as with the Old Testament, turns in the New Testament. He reads the passage while many laity follow along in pew Bibles. A default practice is to then preach extemporaneously through the passage, line-by-line, although cross-referencing and other passage-specific handling are common alternatives. A sermon lasts for about 30 minutes. The minister then sits, the leaders quietly and briefly confer, and then a second minister rises to the pulpit to comment. He then asks for a hymn, a congregant provides a number in Zion's Harp, and the song leader starts it. The second leader rises to the pulpit again, asking for a brother (or visiting brother) to close in prayer. After a pause, someone says, “let's pray" and another man brings him a portable microphone. He delivers an audible prayer, not generally as long as the first prayer but still not less than three minutes.

After the "amen," the Apostolics have a practice no other plain Anabaptists have ritualized to this extent: "the greeting." A leader asks for greetings of the assembled. If someone is visiting from another congregation or had in previous weeks visited another congregation, then the person will say "Greetings from Eureka," or whatever town-name this other church goes by. Generally, leaders offer greetings first, then men, from front to back, stand-and-sit quickly, just long enough to give greetings, with the leader at the pulpit repeating the greeting for all to hear. Women visiting without men may alert a local man before the service to express her greetings. 
When finished, the leader requests visitors take back greetings to home congregations. If announcements are available, the leader makes them at this time.

The leader then invites all to stay for lunch and selects a hymn out of the Zion's Harp; the song leader starts it. Upon the hymn's conclusion, men and women file out to the foyer and ultimately to the cafeteria, the leaders beginning two lines down the center aisle with men and women from the front pews filing out, walking side-by-side, and with each successive pew's occupants following. Somewhere towards the back, the succession ceases before all leave in this manner, especially common in congregations where all cannot be seated initially for the meal.

In older meetinghouses, the dining hall is on the lower floor, which has tables and seats. In newer meetinghouses (Figure 2), the dining hall is across the foyer and has stool-and-counter seating, as at a diner. The counter is a U-shape with a short $180^{\circ}$ bend and long arms. Trays of food are staggered every several seats so all can reach. Napkins are available as a place-setting. Men and women sit separately, while women who are assisting the hosts go to both sides to fill glasses, refill trays, rotate items to ensure even distribution, and wipe down counters. (On one occasion, my attempt to leave a tip triggered chuckles.) Families host the meal in rotation; for a small church, turns come frequently, while for large churches, a turn may come only every several years; when it comes, the bill may run well over $\$ 1,000$.

After all (or as many as possible) are seated, a man offers a prayer of under one minute. The meal is entirely finger-foods. The food consists of some sort of sandwich-at its most basic, a stack of meat, cheese, and bread. Vegetables-lettuce, tomato, carrots, and other items added to sandwiches or consumed individually_are to the side. Pitchers of milk, coffee, tea, and water are passed around or served. An assortment of small, handheld pastries tops off the meal; even in the smallest of churches, the pastry sampling is impressive. I have had no Apostolic quarrel over my suggestion that the sandwich is something to get out of the way; the meal is all about the pastries.

This communal meal is rare in plain Anabaptist denominations, found only among the Old Order River Brethren (consisting of picnic style foods) and the Amish, which the Apostolic meal closely resembles. Because the Nazarenes of Eastern European descent do not have a shared meal between services - they go home for a meal and return much later in the afternoon for a second service - and given the resemblance between the Amish and Apostolic meal, in all probability, Amish-Mennonite converts of the mid-1800s brought this practice into the ACCA.

As members finish their meals, they independently bow heads for a silent prayer and casually move to the foyer, interspersed with conversations on the way. The afternoon service, a replica of the morning service, will soon begin. Attendees start assembling in the sanctuary and begin singing out of Hymns of Zion, an Apostolic hymnal incorporating many $18^{\text {th }}$ and early $19^{\text {th }}$ century gospel songs familiar to evangelical Protestants. Singing is the cue for others to move towards the sanctuary. As congregants move towards the service's opening, they switch to Zion's 
Harp. The only differences between the morning and afternoon service is that hymns from the Hymns of Zion are more likely to be selected, a different leader will share, and a truncated opportunity for greetings is offered, in case any were missed from the morning hour or new people have since joined the service.

Attendees congregate in the foyer for informal conversation before leaving. For more conservative settings and individuals, a handshake is extended on departure with the phrase, "Farewell, brother / sister" and, in even more conservative settings, a farewell cheek-to-cheek kiss within each gender. Before stepping outside, women remove their outer covering, fold it, and deposit it into a purse or handbag. Visitors who have no other plans may be invited to a home for the afternoon, as well as an evening meal, which is more substantial and often includes other guests.

What is described above is the pattern of at least a past generation, so is a conservative description against which any variation is measured. Indeed, variation now exists among Apostolic services. The consulting among leaders prior to a minister giving an opening may be much shorter and less ceremonial, barely noticeable. A leader's opening may be lengthy, a topic unto itself prior to opening the Bible. After the Bible-opening, pre-meditated and/or thematic sermons deviating from the passage-which is framed as an inspirational thought rather than source-text - are characteristic of progressives. In some cases, the Bible may not be opened at all and the pre-meditated topic given instead. Alternatively, a passage may be deliberately selected instead of opened to at random. Lengthy openings and alternative topics usually address themes familiar to non-denominational, contemporary Christian leadership, a format that borrows from corporate-style motivational talks. In greetings, leaders may not simply echo what is shared from laity but provide personalized comments. Hymns may be a greater mix from the Hymns of Zion. Interpersonal "greeting”s and “farewell”s are omitted. Lunch menus may be more elaborate, especially what is considered a sandwich (e.g. subs, wraps, sliders, and pizza). Women may wear their covering inconspicuously, using fairly sheer, shorter pieces and placing them on or in the bun, frilling it outwardly and downwardly, as if an ornamental hair accessory. Men's and women's church dress is in the style of business and business casual, e.g. men's khakis and decorative ties, if a tie at all; women's form-flattering secretary-style dresses.

Conservative ACCNs and assumedly all NCCs have two sermons, usually one in English and a shorter one in an Eastern European language. For greetings and announcements, they dismisses non-members, including their own children. The reason, it is said, is because in communist times, they did not want to give away the locations of other churches should a spy be present. If this is so, the practice must have become common during the mid-20 ${ }^{\text {th }}$ century migration and not since the beginning of the ACCN in America. 


\section{Main Teachings and Practices}

The Apostolic Christian Church of America Statement of Faith includes 20 points, many similar to other plain Anabaptist statements. In addition to familiar, orthodox Christian beliefs about God, Jesus, the Holy Spirit, original sin, redemption, and final salvation and damnation, the Apostolics also include statements about baptism following true repentance and conversion, non-swearing of oaths, non-violence (with an emphasis on accepting non-combatant positions if drafted), a ministry ordained from the laity, closed communion, the kiss of charity among members of the same gender, the permanence of marriage, the possibility of falling away from the faith, the woman's head covering, separation and non-conformity, and the importance of the true believers joining themselves to a "close-knit" church.

What characterizes the Apostolics as distinct from other plain Anabaptists is, then, not to be found in their explicit statement of doctrine but rather in a constellation of small practices. The following, then, is my attempt to organize this constellation into four major emphases, the product of many observations, conversations, and inductions with Apostolics and comparing it against the religious life of other plain Anabaptists. In positing four, I am not advancing four as complete, nor am I defending fixed boundaries among the four, nor are any of these four necessarily exclusive to the Apostolics. Rather, I offer them as an opener to exploring the Apostolic collective religious personality, the essences of their identity. I will also stress that they tend to represent the conservative side, since what is defined as conservative is that which is characteristic of the Apostolic's distinct offerings and is resistant to hybridization to other forces.

\section{(1) True Repentance and Death of the Old Man}

The Apostolic rite of passage through religious conversion is one of the most sequential in all of plain Anabaptism. Most facets are not necessarily unique to Apostolics but their amplification is. For one, Apostolics generally view the conversion sequence as rigorously introspective and therefore genuine, at a level of depth not found with such consistency among other Anabaptists or theologically proximate Protestants.

As with other Anabaptists, baptism is reserved for those who have entered into the age of accountability (beyond childhood). But between childhood and repentance, Apostolics have the designation of "friend" of the church. This is an overtly defined role, not just the term for a goodnatured associate. Friends are those who participate in the social life of the church but have not "begun repenting." So defined is this role that friends can be numbered into a fixed roster as members can be. While friends are generally the children of members, they also include any somewhat regular attendees who have no other primary church. Friends are the pool from which converts come.

The role of friend especially facilitates the Apostolic emphasis on genuine conversion, because it permits potential converts to partake in most aspects of church life stigma-free, thus removing role-induced pressure to join (not that all pressures, such as family-pressure, are 
omitted). Apostolic elders will even accommodate friends by marrying them, though the wedding cannot occur in an Apostolic meetinghouse. This arrangement contrasts with the Amish and Mennonites, who allow unbaptized young adults at age 16 to run with the young people but with the clock always ticking for a baptism decision. By a young adult's early 20s among Amish and Mennonites, if he continues participating in the social life of the church yet has not decided to be baptized and join the church, his presence will be stigmatized as an ever-growing source of strain. Not so for the Apostolics- he can be a friend right up to and through his senior years, though a lifelong friend is rare.

Friends move toward baptism when they "begin repenting"-and repenting is in present progressive tense, because it is a state of enactment at any moment. The decision to begin repenting is highly personalized, the details of which are retold again and again throughout one's life in story form. One may think, now, of the evangelical's emphasis on the "testimony" of conversion, recalling the exact moment when he experienced salvation (Geiger 1986). For the Apostolic, the story may not be of a precise moment so much as a decision arising from inward conviction to address moral burdens carried. The story is an internal struggle of the will to yield to God's holiness, not a hallelujah moment of sanctification, which Apostolics view as cheap grace. For when the Apostolic begins repenting, he is engaging in deep, inward searching, followed by concrete action to rectify any past wrongs that come to mind. This will likely include some personal contacts and confessions. This soul-searching may last from several weeks up to two years, with longer repenting periods rare. When the individual feels God has granted his soul rest through the clearing process, he goes to the elder, and a baptism is planned. Baptism is by full immersion in a pool in the sanctuary and occurs during the afternoon service. After the baptism, all members file through to greet the new member.

The outcome of repentance is a conspicuous transformation in the convert's life; hence, true repentance means a noticeable change of ways. Among the first and most obvious changes is in dress, especially in more conservative churches. Men exchange fashionable clothing for toned down apparel. Men wear a simple shirt, often a plaid button-up shirt and remain clean shaven; they may be mistaken for conservative Mennonites. Women will don a blouse (possibly layered) / skirt combination (Figure 5). Atop the head is placed a black or brown covering, crochet or string-style about the size of the hand. Hair is usually in a bun (Figure 6). Unlike most other plain Anabaptists, the prescriptions for dress are basically absent, with the exception of clean shaven for men (now rescinded as of autumn 2017 by the ACCA Elder Body, though permitted unevenly at local churches) and skirt for women (which the progressive end now observes with irregularity).

A second realm of change concerns activities. Many Apostolics speak of their involvement in competitive sports prior to conversion, especially those played in public high school. After conversion, Apostolics generally abstain from all competitive sports, including attendance at high school games and even in-group leisure softball and volleyball, a restriction most plain Anabaptists would not hold. At one time, higher education was not accepted, although 
Figure 5: Characteristic Everyday Dress of Apostolics

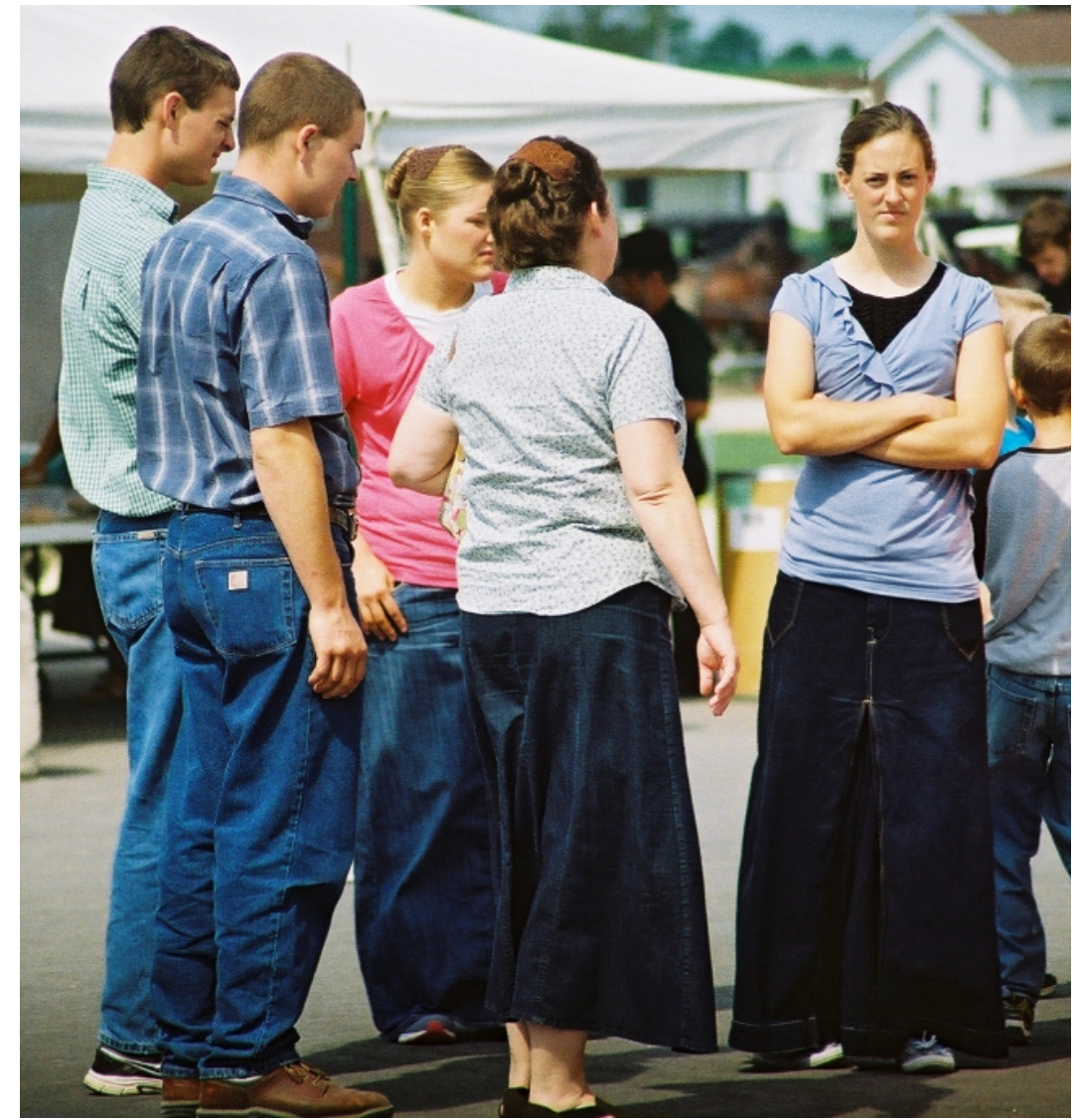

Photo by Cory Anderson

Figure 6: A Woman's Everyday Covering, Crochet (Left) and String (Right)
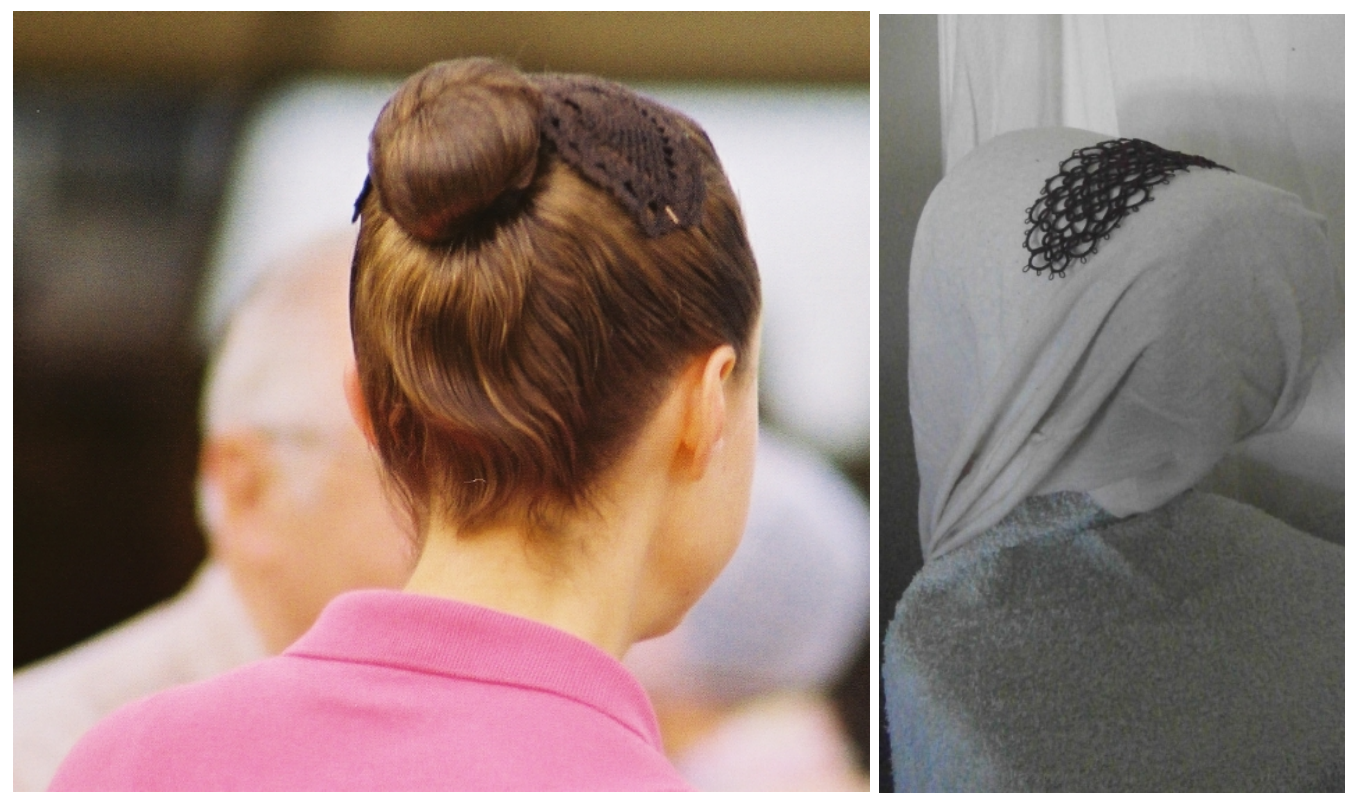

Photos by Cory Anderson 
this position has softened the past two to three decades. Similarly, at one time, Apostolic occupations were primarily rural and labor-based; today, especially with higher education, a good many are in professional occupations, working with little to no other co-religionists. Combatant military service is rejected, and while Apostolics do not get involved in political activism or hold political office, they do not reject patriotism. It's not uncommon to find American flags on Apostolic properties, and many Apostolics have no qualms about voting. Their current preference is heavily Republican, as is true of nearly all plain people if they can be drawn into politics. Distinction in activities also carries to within the church, notably in that the singles' (young adult) groups are separated between the friends and the members.

Beyond dress and activities, the whole demeanor and personality is expected to change to represent the repentance transformation. So important is this particular transformation that parents provide relatively little bridle for their children, especially the pre-adolescents, who engage in excessively kinetic gesticulation and activity plus heavy whispering during the church service and other public affairs. It's possible that this unrestraint and self-consumption helps feed an "I’m sick of myself” consciousness coinciding with the awakening of repentance.

The believer is not to sin, and the goal of the brotherhood is to be sin-free. Certainly this call to a walk of holiness is paralleled among the Amish, Russian Mennonites, Swiss Mennonites, Hutterites, and German Baptists, indeed, is a theology that helps define the plain Anabaptists. However, the theological nuances are greater for the Apostolics. The historic position of Apostolics is that the blood Jesus shed in his crucifixion is for the sins of all mankind prior to repentance. Thereafter, if the believer sins, he has an advocate in Christ, Who sits at God's right hand. Nevertheless, such sins are serious, and believers are to be careful in their walk so as not to sin. Sin is a grievance to God, to be faced with regret, not an occasion to celebrate Jesus, who mechanically vends forgiveness to the "born again.” Apostolics also identify "sins unto death,"8 through which one cannot be restored to the church; the church releases judgment to God. The two most well-known are murder and fornication / adultery, the latter being basically the only sin unto death ever dealt with. The Apostolic view of sins after repenting and sins unto death buoys their idea of true repentance, and more generally, the plain Anabaptist notion that the believer can backslide and fall out of God's grace, a position in contrast to Calvinist predestination - that one is predetermined to heaven or hell—or the "once saved, always saved" doctrine - that one can sin freely and no sin can take one away from Jesus's grace once it is first accepted.

\section{(2) Gentle, Reasoned Pleading}

The second theme pertains to how Apostolics approach imparting religiosity to each other, particularly in preaching, but in a style that spills into other areas. If evangelical Christian sermons could be characterized as colloquial, oratorical, and first person- / self-oriented, with particular focus on the personal testimony and invitation (Geiger 1986), and Amish sermons as 
rapid, formulaic, introspective, and experiential, with many verbatim quotations (Dow 1989; Enninger and Raith 1981), Apostolic sermons would be gentle, reasoned pleading:

- gentle_-as in, collectively warm and intimate, but not in the sense of interpersonal intimacy characteristic of individualistic, emotionalist relationships common in popular Christianity

- reasoned-logical, with thought-building-upon-thought moving towards a deduction

- pleading - as in, treating the other as in control over his affairs, unable to be tricked or cajoled into a decision

The typical classic Apostolic sermon is spoken in a major key. The pace is moderate and measured. The tone is soft, somewhat contemplative. Beyond these characteristics, the sermon has a paucity of oratorical techniques that could be used to trigger audience emotions, such as gesticulation, charismatic oratory, dramatic pauses, and walking away from the pulpit. The gentle, reasoned pleading generally focuses on two audiences. The first are the friends, pleading for them to consider their ways and to come to repentance. The second are the brothers and sisters, to continue walking in righteousness and to be on guard for gradually falling away. The gentleness of the plea comes not only in delivery but also in repeated phrases. The preacher addresses the audience as "dear ones" or "loved ones" or specifically to the "brothers and sisters" or "friends." As with the Amish, who have a specific form of preaching, the preaching style of the Apostolics has a built-in form that minimizes individual charisma and effectively subverts the individual to the role of preacher rather than permitting the individual to shape the role with personal charisma. Thus, the preaching style lends itself to a familiar collectivist-oriented Anabaptist ethos, where leaders' sermons capture the reflections, empathies, and meditative thoughts of the collectivity, with as little attention on the individual himself who is speaking. This is in contrast to many contemporary evangelical / non-denominational sermons, which consist of a strong emphasis on the individual charisma of the speaker and his work to motivate, persuade, or move an audience.

This style of preaching carries over to the way members entreat one another. Of note, Apostolics are quick to pick up on something awry in another member's life, perhaps a straying or a foreign behavior, and approach one another more directly. For example, a sister who started wearing a larger head covering during the week found her covering a very common topic of conversation, her interlocutors often asking why the common practice and size were not adequate. As another example, during the recent ACCA-ACF division, many, many phone calls were made to individuals leaning towards the new movement, to plea, to reason with them not to go. An individual making steps in a direction away from the Apostolics was worn down from the telephone ringing incessantly, brothers and sisters calling him, finding out what was going on and pleading with him to stop this path or to consider other options. Likewise, those stepping out to go with the Faith Church received calls and encouragement from others going to remain strong and stick with it. 
Such contacts are made when a sufficiently represented opinion gives courage for a member to make his plea to another. This is a more direct approach than most other Anabaptists embrace, the Hutterites excepting. For the sake of comparison, among the Amish, deviance is rarely dealt with forthrightly on a lay level. Rather, to communicate disapproval, members make subtle inferences to the offender, spoken and unspoken, even just in the way a glance is cast, and they mobilize sympathy by discussing the offense with others to gauge their opinion. If these indirect methods are ineffective, members may then make casual round-about mention of the infraction to leadership, who then must choose whether to confront a member directly or let the infraction slide. In sum, Amish tend to talk the problem around in hopes of stigmatizing the behavior indirectly (Cong 1992; Hamilton and Hawley 1999).

For Apostolics, if the offense is one where the Church's sympathies are unclear, the matter becomes one for ministers to address. Rather than directly censuring the individual, ministers will converse with them on an interpersonal basis to understand the nature and cause of the infraction. The offense then becomes one of motives and seeds rather than action and behavior, bearing strong resemblance to the Holdeman Mennonite approach. The Amish and Mennonites tend to approach infractions with an appeal to a member's agreement and commitment to the church code. The Apostolic minister's approach is one of personally pleading to the individual through a reasoned discourse rather than stirring reminder of church codes.

\section{(3) Affectionate Fraternity of the Repentant}

The Apostolics demonstrate a sentimental affection for their people akin to that of the Brethren (German Baptists). This affection is not a mere loyalty arising from ethnicity or organizational commitment; rather, their loyalty is as a fraternity, a voluntary union not predicated on common blood but on religiously-based decisions. This affection is sentimental, markedly different from other plain churches, who, even as they are snuggly packed into a tight social network, tend more toward critical evaluation of their church, its leaders, and those members diverging in practice and thought.

Apostolic affection has been routinized into several practices that remind members of this affectionate fraternity. On meeting, the salutation "Greetings brother / sister," the soft hand shake, and the Christian kiss, as well as the mirrored departing ritual, is an affectionate act. Between congregations, Apostolics extend "greetings" from other people when informally visiting each other. In the formal greetings at the church service, the name of a town is mentioned. Sentiment is attached to these town names, so that even their mention is a form of affectionate bonding.

One story well illustrates this affection. A family of Apostolics traveling on the interstate in the U.S. Southwest suspected that a vehicle they passed contained Apostolics. Wanting to know, they fell into pace with the other vehicle and raised a sign to the other car: "West Bend." After a scramble, the others reciprocated with their own sign: "Latty." Both families far from 
home, they managed to solicit fraternal affectionate over two catch-words- town namesassociated with “our people.” Were Amish and Mennonites in this situation, they might be inquisitive to place the others in a web of interconnectedness - settlements, family relationships, and so forth-but to call any discoveries of social situation "affection" would be a stretch. The symbolic currency assigned these town names is further evidenced by the fact that when the recent division occurred in 2012, the congregations of the new group, though basically in the same areas as the congregations from which they withdrew, selected another nearby town for their church name.

Another practice of the affectionate fraternity is sharing meals. Within church is the Sunday shared meal, where affection is not only demonstrated in "breaking bread" together but in the opportunity to occasionally furnish and serve the meal. Apostolics also host each other in their homes for a meal and visiting, often on Sunday evenings. Yet another practice is the frequency of services; a typical Sunday includes a late morning and early afternoon service and often includes an evening service. A midweek service is frequently held. Other activities populate the monthly calendar for "groups" including the friends and singles. Apostolics get together, a lot.

The Apostolics would not appear to hold their equivalent of the Ordnung or church practices to a high level. Yet, latently, the importance of their mundane, everyday practices in defining the religious side of their peoplehood is certainly comparable to the other plain churches. Compared to Amish and Mennonites, sanctions for observance source less from church leadership \& informal pressures and more from a desire for oneness through affection, though not to the exclusion of leadership and informal pressure. A similar emphasis is found among the Holdeman Mennonites and the Old Order River Brethren, who lean toward the thought_-”If you are drawn to the brotherhood, then you will want to be like the brotherhood"-as a mechanism to maintain a unified religious sense of peoplehood. The total affection for the brotherhood is then measured through a uniformity in religious traditions and practices that speak of Godliness.

Most plain Anabaptist churches, affiliations, or settlements inevitably develop a list of familiar surnames due to endogamy and low in-conversion. Ethnicity and genealogies have been important to the Amish at least since the late 1800s, long before it was popular for people to track their ancestors (Luthy 1985). These genealogies contribute to plain Anabaptist ethnicity as people sharing a common faith and heritage (Enninger 1986). Ethnicity is important to most plain groups to the extent that clans, as social entities, often compete for allegiances with the local congregation, e.g. certain extended families may be commonly placed in the ministry while other families carry a moderate stigma, or, family reunions of one scale or another occur annually, and each married couple will annually attend at least two, if not more, and the family may have their own church service if the reunion is over a Sunday and minister present.

Given the Apostolics’ practice of endogamy and the resultant pool of common surnames, we could reasonably expect the same genealogy-clan dynamic among Apostolics. Extended 
family as a social entity, while still very important, is, however, subjected to the affectionate fraternization of believers, evident in the following ways.

First, while lay people among the Amish and Mennonites visit other congregations and settlements as a matter of having family there, Apostolics are much more liable to plan trips around visits to congregations they do not have family in, or even that they may not know the people well. They generally want to visit congregations to get to know others better.

Second, and similar to the Amish (Enninger and Raith 1982), Apostolics ritualistically and symbolically dismantle the social unit "family" upon arrival at church and only reassemble it upon egress. This ritual role transition from family member to brother / sister / friend / child is facilitated through gender-specific greeting forms, seating in the church service, and meal seating. Foyers facilitate some across-gender interaction between morning and afternoon church services, though does not facilitate reassembly of family roles.

Third, church leadership is much more involved in the facilitation of marriage proposals and ceremonies (the practice is discussed below) than most other plain Anabaptists, who generally leave to couples and families such matters until a wedding ceremony is requested. Hence, the church, in closely intermediating the formation of couples and marriages, symbolizes its indispensible centrality to family life.

Finally, Apostolics are slightly more flexible in accepting into the church remarried couples who have divorced spouses still living. For a divorce and remarriage to have occurred prior to repentance is prerequisite to a church accepting such a couple. The church would not, however, accept divorce among members, let alone remarriage. Through this arrangement, the Apostolics accent the family unit's subjugation to the church by symbolically ranking marriages solemnized outside the church as of less value to those processed through the church. Apostolics, thus, stay true to the no-divorce-and-remarriage position common across plain Anabaptists while also allowing an exception that elevates marriages performed within the church. The only other major plain Anabaptist group that accepts remarried couples into membership under such conditions is the Holdeman Mennonites.

With an affectionate fraternization comes an inverse practice: non-fraternization. Apostolics may not visit the church services of other denominations. They may visit the services of sister churches within the Apostolic tradition, although even this appears slightly stigmatized, and it seldom occurs in practice. The rationale for non-fraternization is to not bring in doctrinal confusion, and it extends to not having religious books of other denominations or joining together on religious projects. In reality, what Apostolics call "new evangelical” doctrine (mainly of Baptists and contemporary non-denominational Christianity) has long saturated the thought of some Apostolics, so its additional purpose is found in ensuring people's religious institutional focus remains exclusively on the body they joined even as their theological loyalties are hybridized. 
The nature of this non-fraternization doctrine is more easily determined as levels of intensity plotted along a continuum. In its stricter form, the German Apostolic Christian Church does not permit casual visitors into their worship services, nor do they permit visiting any other Apostolic services, even to witness rites of passage. Furthermore, they withdraw from any conversation with outsiders that moves to a religious subject. For the NCC., non-members may attend regular services although are dismissed at the end of the service for a members-only meeting, to exchange greetings. Baptismal and wedding services are also closed to nonmembers. In non-fraternization's lenient forms, attendance at special services (e.g. funerals and weddings) of other denominations is acceptable, as is some casual fraternization with other Christians in the workplace and university setting. Furthermore, private consumption of new evangelical media_-books, recorded sermons, training materials, television evangelists, etc. - is condoned.

The affection for the fraternity is demonstrated in the long forbearance Apostolics have with one another. To avoid division, Apostolics sort themselves according to conservative and progressive poles, with churches inheriting reputations and visiting patterns aligned accordingly. The Elder Body has long managed to address the conservatives’ concerns while not totally alienating the progressives' liberties. Thus, the Apostolics in America have had but three divisions; only the Holdeman Mennonites with several very small divisions in the 1950s-70s, the Reformed Mennonites with two divisions, and the three Hutterite branches with only one major division among the three (within the Schmiedeleut) claim fewer divisions over the same amount of time. Yet, the three Apostolic divisions were very bitter, wrecking affection and sentiments.

After divisions, the Apostolic affection is converted into feelings of betrayal, bitterness, and pain. Most Amish and Mennonite affiliations have semi-institutionalized divisions, with parties going their ways under comparatively mild accusations and in predictable ways (e.g. Mennonite ministers walking out of a conference meeting or an Amish minister at the end of the service announcing a second location for meeting in two weeks). For Apostolics, total apostasy is typically prescribed to the other party. In the recent 2012 division, the conservative faction accused the mother church of apostatizing from the way of truth and listed the specific practices the Elder Body no longer defended in action. Those in the ACCA opposing the division branded it as exchanging the true faith and original Apostolic church for traditionalism, rejection of the Spirit that leads friends to repentance, and a road toward eventual elder totalitarianism. Speaking only one sentence about them, one ACCA man told me, "The Faith will self-destruct because they will never be perfect enough.” Nonviolent holy war seems the consequence of the rare division in a religion praising the affectionate fraternity.

\section{(4) The Personal Leading of the Spirit through the Church}

Apostolics stress that the Spirit leads and prompts individuals. This leading is not synonymous with the strong sense of individualistic religiosity prevalent in modern American Christianity. Rather, the church mediates the Spirit's leading by infusing its invocation into 
collectively conscious rites of passage and rituals. The foremost prompting, indeed the Spirit's first act, is to convict friends to repentance, a process as thoroughly introspective as it is groupreferencing.

The church presents many occasions to remind believers of the Spirit's leading. Often, a leader invites a volunteer from the assembled laymen to offer a prayer or hymn selection in the service or a prayer before the meal at church or in homes. Leaders preach on rotation, although this is not confirmed until leaders confer immediately after an opening silent prayer in the service. In this moment, encouragement to let the Spirit lead, I am told, is passed from other leaders to the one who is about to preach. The practice of preaching from a randomly opened Bible passage by-design subordinates the individual's charisma and personal intellect to the role of "minister," in much the same way that, among the Amish, the absence of notes and a singsong intonation preaching style subjects the minister's individual charisma to his churchappointed role of leader rather than the individual using the role as a personal bully pulpit (Enninger and Raith 1981).

The most intriguing of all Spirit-leading practices is "faith marriage." As the course of nature goes, Apostolic singles develop attractions to the opposite gender. Ideally, though, singles pray intensely that God would remove these feelings, if it be His will. If, however, the feelings persist despite an honest desire to yield to the Spirit, then this may be the Spirit leading a young person to another. As the men are charged with initiating a request, women simply pray the feelings away, if it be God's will. Because Apostolics proscribe dating and courtship—viewed as frivolous activities of self-centered passion-arousing convoluting the Spirit's voice-a man, when making a request of a woman, is asking for engagement.

To make a request, the man will contact his elder and discuss the prospect. If both agree the interest is of the Spirit, then the elder will communicate to the single woman that a proposal has been made; if the single woman is in another congregation, the man's elder will communicate with her elder, who will communicate the proposal. Typically, the woman will withdraw herself for some days to pray, at which point she will either return to the elder with a "no" or a request for the name. After the name is given, she will once again pray, especially that God would not allow her personal feelings about this man to interfere with His Spirit's promptings. She then gives the elder a yes or no, which is relayed to the man. For a woman to say "yes" without a name-trusting the Spirit that this is His will and wanting not her own feelings to interfere-is extremely rare and is the stuff of Apostolic legends. Another story in circulation from many years ago was the name mix-up, where the young man's proposal was made to the wrong woman, who consented to his proposal. He accepted this as God's will. Apostolics relate these kinds of stories partially in amusement, partially in admiration, partially in deference to the supremacy of this easy-for-outsiders-to-criticize practice. Some singles, of course, never marry, both men and women, and they accept this as God's will. Women are simply never asked, while the respectable explanation for men is that they simply never felt led or that a carefully made request or two was not accepted, suggesting God has other plans. 
Certainly, due to this view, bachelors among Apostolics retain more status than they do in other plain churches, where non-marriage is seen as a failure or a matter of handicap.

While faith marriage is extremely personal, the entire process occurs through the context and channels of the church. Endogamy is practiced, prospective couples discover each other through church activities and visiting, elders monitor the readiness of individuals and can veto requests (discriminately and occasionally), the engagement is first announced from the pulpit at a service's conclusion, and the church is quite involved with the engaged couple from their announcement to the wedding day only several weeks to months later. Thus, the Spirit's leading for a wife or husband is both personal and church-conscious.

The Apostolic view of the Spirit's activity in churches means that someone must be really wrong when divisions occur, for a division is the failure of the Spirit to work in some members' lives. Commonly, each side will state that the other side is being led by a different (evil) spirit. This sweeping conclusion evidences the Apostolic view that the Spirit's personal leading is inseparable from the church context. The Spirit will not lead people away from His Church, be it through institutional drift or sectarian division.

Most other plain Anabaptists do not emphasize doctrines of the Holy Spirit, tending to concede the Spirit to one's personal life on the condition that individuals make no claim that the Spirit is leading them in ways contradicting the church's decisions. Thus, the Apostolic model of the Spirit's leading, though differing in some ways from other plain Anabaptists, is certainly orthodox to historic Anabaptist thought, just a bit more central to collective life.

\section{Conclusion}

Apostolics are an attractive group to study because many of the salient symbols and practices that catch the attention of researchers about other groups-conspicuously distinct dress, technology restrictions, communalist economic systems, and such-are absent among the Apostolics, yet forces nevertheless exist that define the Apostolic Christian Church as such and bind them together. The Apostolic case reminds us that what researchers latch onto in defining the different plain traditions, especially the Amish, may be manifestations of some deeper set of cultural personality traits that better define a plain tradition and provide social glue (Good Gingrich 2016; Reschly 2000).

This article, and special section of JAPAS, is a call for researchers to take an interest in the Apostolics, if not specifically, at least in a comparative capacity. Specifically, much room remains for researchers to:

1. Provide more nuanced histories of the Apostolic churches

2. Explore the European churches more, which are an intriguing case of plain Anabaptist continuity in Europe whereas all other traditions have little (Bruderhof and Russian Mennonites) to no continuity (Amish, Swiss Mennonites, Brethren, and Hutterites) 
3. Conduct comparative studies of European and American bodies

4. Analyze the tremendous social changes the Apostolics have experienced in the mid- $20^{\text {th }}$ century to present

5. Further characterize the Apostolic collective "personality" (the collective habitus) that helps define the Apostolics

One final emphasis is that researchers should pay particular attention to the Apostolic Christian Church of America these next years. This body is at an historic threshold right now, with an uncertain outcome before them that will conclude somewhere between a retrenchment / restatement of core Apostolic values with some newly sanctioned hybrids of thought / practice and total assimilation.

Some members, especially in the generation and demographic of the young to middleaged and married, have televisions at home, attend sports events, and — specifically the womenwear pants, no covering, and hair down. Certainly, internet on phones and computers has contributed to shifts in religious thinking in this age; McClure (2017) recently found that internet use predicts a decline in exclusivism and a rise in feelings of non-denominationalism. That loosely committed members exist side-by-side in churches with members observing historic practices suggests either a leadership stalemate or proactive interception of disciplinary measures within the Elder Body.

The tensions Apostolics face are not unique among plain Anabaptists, as many other groups grapple with lackadaisical member commitments to the church. They also grapple with institutional, leadership, and power questions. Specifically, restless times see a rise in leaders who master the trusted religious language and institutional forms but use it to "own" old practices for the sake of reframing them into new, hybridized reinventions.

Should assimilation occur, the number of "plain” Apostolic members in North America will remain in the Faith church and the other small bodies, which number only a little over 1,000. Should something in-between occur, a great opportunity exists to explore the nature of a conservative-mainstream fringe Anabaptist affiliation.

\section{Endnotes}

${ }^{1}$ Nazarean appears preferred now to Nazarene. I can only guess the change was to reduce confusion with the unrelated Church of the Nazarene.

${ }^{2}$ See http://responsetoacpreservationmovement.blogspot.com

${ }^{3}$ Including "A History of the Transition from an Apostolic Believing Church to a New Evangelical Church” (2012) by Kurt Ehnle, and, Biblical Foundations of the New Testament Church: A Presentation of the Historic Apostolic Christian Faith (2010) by Ben Rufener, Brian Miller, Cliff Brake, Dan Dubach, Matt Bauman, and Steve Warner. 
${ }^{4}$ It was originally prepared and signed by Peter Petrovic (San Diego, CA), Lawrence Luthi (Lamar, MO), David Graf (Akron, OH), Wayne Grimm (West Bend, IA), and Ben Walder (Congerville, IL) in 2010. The restatement in 2012 was signed by Elders Roy Koehl (Morris, MN) Art Nohl (Morris, MN), Dennis Warner (Lester, IA), Lawrence Luthi (Lamar, MO), and Gene Marti (Sabetha, KS).

${ }^{5}$ Near the time of publishing, I heard that the ACF elders may have decided to allow couples currently in a divorce-remarriage state to remain but no new members will be accepted. I have not yet been able to directly verify this outcome.

${ }^{6}$ These unpublished figures are from the research of Karsten Albertsen, provided here with his consent.

${ }^{7}$ Numbers are estimates provided by an NCC member to the author (2015) and another NCC member to Christopher Petrovich (2018).

${ }^{8}$ From the New Testament book of 1 John: 5:16-17 "If any man see his brother sin a sin which is not unto death, he shall ask, and he shall give him life for them that sin not unto death. There is a sin unto death: I do not say that he shall pray for it. All unrighteousness is sin: and there is a sin not unto death."

\section{References}

Anderson, Cory. 2013. "Who Are the Plain Anabaptists? What Are the Plain Anabaptists?” Journal of Amish and Plain Anabaptist Studies 1(1):26-71.

https://doi.org/10.18061/1811/54897

Bojan, Aleksov. 1999. “The Dynamics of Extinction: The Nazarene Religious Community in Yugoslavia after 1945.” M.A. thesis in History. Budapest, Hungary: Central European University.

Cong, Dachang. 1992. “Amish Factionalism and Technological Change: A Case Study of Kerosene Refrigerators and Conservatism.” Ethnology 31(3):205-14. https://doi.org/10.2307/3773527

Djurić-Milovanović, Aleksandra. 2010. “Conservative Neo-Protestants: Romanian Nazarenes in Serbia.” Occasional Papers on Religion in Eastern Europe 30(3).

Djurić-Milovanović, Aleksandra. 2018. “'Our Faith Is Good, but Strict': The Transformation of the Apostolic Christian Church-Nazarene in North America.” Journal of Amish and Plain Anabaptist Studies 6(1):61-72.

Dow, James. 1989. “Chiasmus, Structural Symmetry, and Nonverbal Communication: Toward an Understanding of the Old Order Amish Gemee.” Pp. 125-34 in Studies on the 
Languages and the Verbal Behavior of the Pennsylvania Germans II, edited by Werner Enninger, Joachim Raith and Karl-Heinz Wandt. Stuttgart, Germany: Franz Steiner Verlag Wiesbaden GMBH.

Ehnle, Kurt, and Jane Ehnle. 2011. Heritage of Faith: A History of the Church with an Apostolic Christian Focus. Edelstein, IL: Heritage Press.

Enninger, Werner, and Joachim Raith. 1981. "Linguistic Modalities of Liturgical Registers: The Case of the Old Order Amish (OOA) Church Service.” Yearbook of GermanAmerican Studies 16:115-29.

Enninger, Werner, and Joachim Raith. 1982. An Ethnography-of-Communication Approach to Ceremonial Situations. A Study on Communication in Institutionalized Social Contexts: The Old Order Amish Church Service, Wiesbaden, Germany: Franz Steiner Verlag.

Enninger, Werner. 1986. "The Theme of Ethnicity in the Literature of the Old Order Amish.” Pp. 115-36 in Studies on the Languages and the Verbal Behavior of the Pennsylvania Germans I, edited by Werner Enninger. Stuttgart, Germany: Franz Steiner Verlag Wiesbaden GMBH.

Geiger, Annamaria. 1986. “Communication in American Contexts of Religion: Old Order Amish vs. Born-Agains.” Pp. 148-69 in Internal and External Perspectives on Amish and Mennonite Life 2, Vol. 2, edited by Werner Enninger, Joachim Raith and KarlHeinz Wandt. Essen, Germany: Unipress.

Gingerich, Jason Nelson. 1986. “Ordinance or Ordering: Ordnung and Amish Ministers Meetings, 1862-1878.” Mennonite Quarterly Review 60 (2):180-99.

Good Gingrich, Luann. 2014. "Preserving Cultural Heritage in the Context of Migratory Livelihoods.” International Migration 52(3):1-20. https://doi.org/10.1111/imig.12066

Good Gingrich, Luann. 2016. Out of Place: Social Exclusion and Mennonite Migrants in Canada. Toronto, ON: University of Toronto Press.

Hamilton, Jean, and Jana Hawley. 1999. "Sacred Dress, Public Worlds: Amish and Mormon Experience and Commitment.” Pp. 31-51 in Religion, Dress, and the Body, edited by Gabriella Lazaridis and Linda Arthur. New York, NY: Berg. https://doi.org/10.2752/9781847888839/RELDRBODY0007

Klopfenstein, Perry A. 2008. Marching to Zion: A History of the Apostolic Christian Church of America $\left[2^{\text {nd }}\right.$ ed.]. The Apostolic Christian Church of America.

Kniss, Fred. 1997. Disquiet in the Land: Cultural Conflict in American Mennonite Communities. New Brunswick, NJ: Rutgers University Press. 
Kraybill, Donald, and C. Nelson Hostetter. 2001. Anabaptist World U.S.A. Scottdale, PA: Herald Press.

Kraybill, Donald. 2010. Concise Encyclopedia of Amish, Brethren, Hutterites, and Mennonites. Baltimore, MD: Johns Hopkins University Press.

Luthy, David. 1985. “One Hundred Years of Amish Genealogies, 1885-1985.” Pennsylvania Mennonite Heritage 8(4):28-30.

Luthy, David. 1986. The Amish in America: Settlements That Failed, 1840-1960. Aylmer, ON: Pathway Publications.

McClure, Paul. 2017. "Tinkering with Technology and Religion in the Digital Age: The Effects of Internet Use on Religious Belief, Behavior, and Belonging.” Journal for the Scientific Study of Religion 56(3):481-97. https://doi.org/10.1111/jssr.12365

Nenadov, Kathleen. 2006. Choosing to Suffer Affliction: Self-published.

Nussbaum, Ben, and Derrick Babbs. 2003[1973]. 74 Years of 'South Side' Apostolic Christian Church History. Saunemin, IL: Apostolic Heritage.

Pfeiffer, Joseph. 2010. "Between Remnant and Renewal: A Historical and Comparative Study of the 'Apostolic Christian Church' among Neo-Anabaptist Renewal Movements in Europe and America.” Master of Arts in Theological Studies. Elkhart, IN: Associated Mennonite Biblical Seminary.

Pfeiffer, Joseph. 2018. “The Nineteenth Century Apostolic Christian Church: The Dynamics of the Emergence, Establishment, and Fragmentation of a Neo-Anabaptist Sect.” Journal of Amish and Plain Anabaptist Studies 6(1):1-25.

Reschly, Steven. 2000. The Amish on the Iowa Prairie: 1840-1910. Baltimore, MD: Johns Hopkins University Press.

Reschly, Steven. 2017. "Paradigmatic Paradigm Problems: Theory Issues in Amish Studies.” Journal of Amish and Plain Anabaptist Studies 5(1):66-81. https://doi.org/10.18061/1811/81075 